\title{
Willem Feekes - man and myth
}

\author{
W. W. Geertsema \\ G. Geertsema-Groningen B.V., Groningen, Netherlands
}

Willem Feekes was a remarkable man.

There was the Feekes who, after a full day's drive, would arrive at a trial field abroad, change his grey trousers for an almost white balloon-shaped pair, put on his boots and, regardless of rain or shine, stride from plot to plot for hours, a small straw hat on his large head, tirelessly taking his notes - not one note per plot, but usually three to five -, who in the evening could expansively discuss, at a table always lively for his presence, his recent observations, his continuously evolving theories, displaying his encyclopaedic knowledge of the world of cereal breeders and of the value of each breeder's material.

That was one Feekes.

And there was the Feekes who, not all eyes turned upon him, and in circumstances more private, would give evidence of caution, modesty, shyness even; who was thankful for each proof of understanding and appreciation, in a way that suggested that behind this robust and imposing appearance there dwelled a man of distinct vulnerability.

Of this man, confident and hesitant, robust and vulnerable, I want to talk to you.

Feekes joined our firm at the end of the second World War, in a period that was very difficult for him. Like many Dutchmen in the troubled years before the war and liberation, he, as a student and later as a young research worker, had entertained some sympathy with the ideas of those who asserted they were going to build a new Europe, more social, the Europe of the future.

I remember well that my father also, accustomed to clear and dispassionate judgment, recognized those aspects of the politics of the late thirties. Both, Willem Feekes and Tammo Geertsema, became fierce patriots when the chips were down, with Feekes getting into the awkward predicament, soon after the outbreak of the war, of wanting to dissociate himself from his earlier opinions, doing so, and thereby jeopardizing himself and showing great moral courage.

I believe that one of the reasons that Feekes and my father soon felt a mutual esteem, was that they recognized in each other this moral development occasioned by the events of the thirties and forties.

They had something else in common: both had been well-known sportsmen; Feekes as a skater and also on the pentathlon, my father mainly as a skater. Two men who knew the meaning of courage, endurance and honesty with oneself and therefore also with others. 
Feekes and my father both were adventurers. Feekes in his chosen field, which he approached as an explorer Africa; my father in his trade - from no new enterprise did he shy away - and in his contacts with others: my father held the firm belief that there existed an exceptionally qualified man for each task, and that he would find that man.

Two men who suited each other; also because, in good co-operation, they allowed each other a free run of their own responsibilities and they knew no envy.

I have dwelt on these beginning years with our firm, because much of Feekes' later work was related to that beginning: for more than thirty years he worked in an environment of great freedom, able to devote himself to his favorite subject, the synthetic knowledge of the cereal crop, and to be active in professional organizations, principally the Netherlands Grain Centre, in his dynamic and original way.

We are all aware of Feekes' accomplishments in science. A monument to his work is his own Feekes Scale, which indicates the development stages of the cereal plant; a scale which, especially after 1950, was adopted by very many, and currently is used throughout the world, with or without modifications, for cereals as well as other crops.

If I must summarize his scientific work, I say:

- Feekes Scale

- daylength induction

- disease spectra

- interaction of diseases among themselves and with development

- modification growth types.

As no other of his generation Feekes mastered these complex matters, which may be summed up under the head interaction: interaction of variety, daylength, temperature, water supply, and plant diseases.

Remarkable and daring was that Feekes, in developing his theorems and theories, would not let himself be hampered by a temporary insufficiency of indisputable results of conventional scientific experiments. He arrived at his ideas by what he liked to call the clinical approach. Roughly: if you let your eyes do their work, the truth will come out.

His ideas and theories were widely appreciated, and he had a distinctly permeating effect: via the Netherlands Grain Centre, via young research workers who were close to him, via his long and lively travels (often in the company of one or more companions), and via the piles of tables and annotated graphs which he regularly sent to his friends in the Netherlands and in other countries.

To some, especially breeders of cereal varieties, Feekes was a kind of latterday oracle; some scientists considered him gifted, although unconventional; and others were of the opinion that theories relying so heavily on experience and intuition did not deserve the name of science.

Feekes usually did not care what people thought of him, but sometimes he aid. When he waxed enthusiastic he called those who dared, even if their theories lacked proof, progressive, a word he loved to use, but upon those who would 
rather experiment endlessly than draw conclusions, he bestowed one of two descriptive Dutch nouns, indicating that they excreted either vinegar or small dry Sultanas.

Now I come to one of the facets of Feekes that fascinated me most, and I would not know what else to call it than receptiveness. What I mean is an active, searching openness. Feekes was open to new impressions and ideas. In nature, which he loved passionately, he would literally lose himself in wonder. He looked at things with a child's freshness; his eye was the practiced eye of the painter and author who, because their craft demands, keep looking and so remain closer to the freshness of youth.

Aks yourselves: how many of us can still, on occasion, look with the eyes of a child? We have taught ourselves to concentrate on so-called important matters and to overlook the trivial, everyday things; we are far too preoccupied with our worries and see little more than the image at the end of our own private tunnel.

But Feekes looked, and he saw. And when he was surprised at what he saw, he had a word for it: Remarkable! What he meant was: look, here is something strange, something new, and I will not leave it at that; I want to get to the bottom of it. When Feekes said: Remarkable, he was in his element and one could be certain that after a while, he would discuss in detail the phenomenon observed.

Feekes did not, however, observe phenomena only in the plant kingdom, but also in that of the animals, and especially in that species of primate called Homo sapiens, man with brains.

Feekes tended to approach his fellow-man with the same receptiveness, openness, that was so characteristic of him. This meant that he was open to what people held out to him; his was a fundamental faith in the goodness of man. He mainly saw the good and positive characteristics of his fellow-man, and the more so, as they were closer to him. Naturally he was not spared his disappointments; when his trust was abused, he would sometimes turn the other cheek, but at other times he would get angry, and would promote his malfactors to a position somewhat higher and sideways on the family tree of evolution, that of the bovines.

But on the whole his receptive approach of plant and man compelled admiration and loyalty in many. He was generous, and almost never mean. He liked to make others share in his success, and often tried to create the impression that others had done all the work: he had only sat by, making one or two remarks.

Indeed, those remarks! He could reduce a whole gathering to silent despair, when he tossed some seemingly irrelevant matters into the orderly flow of conversation. Edward de Bono may have named it, but Feekes invented and perfected lateral thinking.

A number of times I had the pleasure of preparing Feekes' writings for wider distribution. He usually wrote his papers in English of German, to reach a larger audience. The difficulty with his papers was that in the first instance they ware 
quite rational, but incomprehensible; and after a first burdensome revision comprehensible, but quite irrational. Only those who did not know Feekes, fail to follow me now. It was because he thought by leaps and bounds. His thoughts were knights and queens; a rook did not exist, not to mention a pawn. Moreover, he considered it quite legitimate to apply the rules of a game of draughts to the game of chess, if it suited him. The artistic skill with which he drew curves through scattergrams in a way to suit him best, was delightful. If scientists with narrow guts experience a slight shiver now, they feel exactly what Feekes would have expected of them.

In my own formal training statistics were considered important. I often differed with Feekes about his argumentation; after discussion and perhaps another run-through of the data nearly always his conclusions proved to be correct. What more would you want?

Feekes was not always patient with others who did not see what he saw.

When in the Netherlands we apply for breeder's rights for a new variety, we have to fill in an application form and sign it, as well as a form describing the new variety. Feekes did this for us. One of the last questions on the description form is: Indicate how this variety differs from other varieties. The answer is supposed to be: it is somewhat taller than 'Aramir', or something similar. Feekes invariably filled in: a wholly unique type.

As you all know this lapidary answer: 'wholly unique type', was the crux of the matter: a new variety, in order to be protected, has to be new, i.e. distinguishable from all other known varieties. This uniqueness is not only a legal requisite at the end of the road, but it is a prerequisite for the original selection, for the decisive choice in an early generation.

Feekes was very good at this selection; to such an extent that he was (and wanted to be) more successful in selecting good varieties from material which had already been prepared by other breeders, than in creating his own broad base for selection. This had of course to do with the unusually fierce competition in wheat breeding, and with the Netherlands being a small open country, where good results could be achieved with varieties selected from foreign material.

But it also had to do with something else: the confidence in which Feekes was personally held by foreign breeders - a confidence that under no circumstances would he steal their F-4, F-5 or F-6 material. Feekes used to express that as follows. 'If I were to drive through France,' he would say, 'or Germany or Holland in summertime, with my car window down for fresh air, and if I had stolen somebody's material, and I would pass that variety in the field, I would hear the wheat whispering on the wind: "I have been stolen, I have been stolen, I have been stolen".'

More than a million kilometers he drove from experimental field to experimental field, always making his minute and massive notes, without ever an unseemly whisper from the wheat fields. 
He was, as our Anglo-Saxon neighbours say, a myth in his own time. Most of those who knew him, could tell stories about his energy, his bonhomie, his original approach and ideas, and also of his appearance which never failed to be striking.

Feekes the man was most complicated, and very modest. For what it is worth, I will conclude with one of the most valuable and best-known of Feekes' theories; which aspect of his character is illumined by it, I leave to you to judge. The name of the theory is the three asses theory. It is:

To breed you need three asses:

One ass for the money,

One ass for the work,

And when a good variety is growing in the field, any ass can find it.

Thank you for your attention. 